\title{
Calcium sources applied to soil can replace leaf application in 'Fuji' apple tree ${ }^{1}$
}

\author{
Moeses Andrigo Danner ${ }^{2}$, Silvia Scariotto ${ }^{3}$, Idemir Citadin², Gener Augusto Penso ${ }^{2}$, Luís César Cassol ${ }^{2}$
}

\section{ABSTRACT}

Calcium increases postharvest conservation of apples. Consequently, several calcium foliar sprays are generally applied to apple trees. Due to the low mobility of calcium in the phloem, foliar sprays may have low efficiency to supply calcium in the fruits. This study aimed to evaluate the efficiency of different sources of calcium applied to the soil, compared to the foliar application, on the content of calcium in the soil, leaves and fruits, on yield and fruit quality of 'Fuji' apple trees. The following treatments were tested: control, soil application of calcium chloride, gypsum, Nitrabor ${ }^{\circledR}$, hydrated lime and pulp sludge, and foliar application of calcium chloride. For all sources in the soil, $80 \mathrm{~kg}$ of calcium ha ${ }^{-1}$ year $^{-1}$ were applied. For the foliar treatment, ten sprays with $0.4 \%$ of calcium chloride were performed. The experiment was conducted in two seasons (2008/2009 and 2009/2010), in a complete randomized blocks design, with four replicates and two apple trees per plot. Even in a soil with high calcium content, the sources of calcium increase the calcium content in the soil and leaves, as well as the firmness of apples stored for 90 days. The use of gypsum and pulp sludge increase the calcium content in the flesh of 'Fuji' apples after two successive applications (2009/2010). The sources of calcium applied to the soil can replace the leaf application commonly used in apple orchards, in order to reduce production costs, provided there is no water restriction in the orchard.

KEY-WORDS: Malus domestica; orchard nutrition; postharvest conservation.

\section{INTRODUCTION}

Cold storage of apples enables their off-season sale and constant availability in the market. However, adequate calcium supply in these fruits is essential to improve storage conservation. Calcium pectate, a constituent of the middle lamella, provides greater rigidity to the cell wall and increases resistance to fungal infection (Tobias et al. 1992, Lara et al.

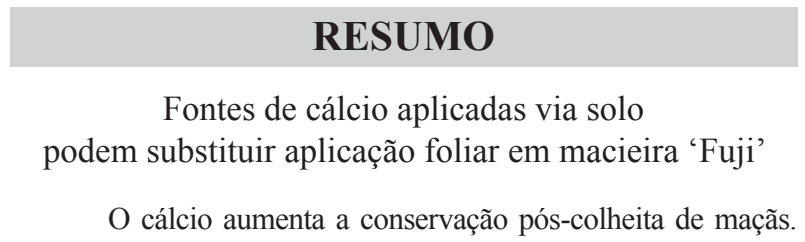
Por isso, são realizadas várias pulverizações via foliar em macieira. Devido à baixa mobilidade do cálcio no floema, a aplicação foliar pode ter baixa eficiência para suprir o cálcio nos frutos. Este trabalho objetivou verificar a eficiência de diferentes fontes de cálcio aplicadas ao solo, em comparação à aplicação foliar, nos teores de cálcio no solo, folhas e frutos, na produtividade e na qualidade de frutos de macieira 'Fuji'. Foram aplicados os seguintes tratamentos: controle, cloreto de cálcio, gesso agrícola, Nitrabor ${ }^{\mathbb{R}}$, cal hidratada e borra de celulose via solo e cloreto de cálcio via foliar. Para todas as fontes utilizadas no solo, aplicaram-se $80 \mathrm{~kg}$ de cálcio ha ${ }^{-1} \mathrm{ano}^{-1}$. No tratamento via foliar foram realizadas dez pulverizações com cloreto de cálcio $0,4 \%$, durante o ciclo. $\mathrm{O}$ experimento foi conduzido em duas safras (2008/2009 e 2009/2010), utilizando-se o delineamento em blocos ao acaso, com quatro repetições, contendo duas macieiras por unidade experimental. Mesmo em solo com alto teor de cálcio, as fontes de cálcio aplicadas aumentam o teor de cálcio no solo e folhas, bem como a firmeza de maçãs armazenadas por 90 dias. O uso de gesso agrícola e de borra de celulose incrementam o cálcio na polpa de maçãs 'Fuji' após duas aplicações sucessivas (2009/2010). As fontes de cálcio aplicadas ao solo podem substituir a aplicação foliar comumente utilizada em pomares de macieira, visando a reduzir os custos de produção, desde que não haja restrição hídrica no pomar.

PALAVRAS-CHAVE: Malus domestica; nutrição de pomares; conservação pós-colheita.

2004, Natale et al. 2005). In addition, apples with low calcium content exhibit severe bitter pit, a physiological disorder that occurs at postharvest and is detrimental to fruit quality (Amarante et al. 2006, 2009 and 2011, Miqueloto et al. 2011, Telias et al. 2006).

Calcium deficiency in fruits can be caused by low calcium supply in the soil and/or water shortage. Calcium uptake and flow into the plant occur through

1. Manuscript received in Mar./2015 and accepted for publication in Jul./2015 (http://dx.doi.org/10.1590/1983-40632015v4534457).

2. Universidade Tecnológica Federal do Paraná (UTFPR), Pato Branco, PR, Brazil.E-mails: moesesdanner@utfpr.edu.br, idemir@utfpr.edu.br, cassol@utfpr.edu.br, generpenso@gmail.com.

3. Universidade Federal de Pelotas (UFPel), Pelotas, RS, Brazil. E-mail: silviascariotto@yahoo.com.br. 
the xylem, after absorption by new roots, and is dependent on transpiration. This means that high calcium and water content in the soil is important to increase the calcium supply to the fruit, particularly during the cell growth period (Ho et al. 1987, Chamel 1989, White \& Broadley 2003).

Calcium accumulation is higher in leaves and branches, with apples containing $14 \%$ of the total calcium absorbed by the tree. Regarding the total calcium accumulated by the fruit, $61.7 \%$ is absorbed from the end of plant growth until harvest (Cheng \& Raba 2009).

In order to supply apples with sufficient calcium to increase postharvest conservation, 8 to 12 foliar sprays of calcium chloride are generally applied in apple orchards from full bloom until harvest. However, some authors have observed different effects on postharvest apple quality after foliar application of calcium. For example, nine foliar applications of $0.6 \%$ calcium chloride increased flesh firmness, reduced rottenness and lowered ethylene production in 'Fuji' apples stored for 9.5 months in a controlled atmosphere $\left(1.2 \mathrm{kPa} \mathrm{O}_{2}\right.$ and $<0.5 \mathrm{kPa}$ of $\mathrm{CO}_{2}$ ), at $-0.5^{\circ} \mathrm{C}$ (Brackmann et al. 2010). However, in five of the six crop seasons assessed, foliar application of $0.5 \%$ calcium chloride showed no effect on bitter pit incidence, calcium concentration or flesh firmness in 'Gala' apples cold stored $\left(-1^{\circ} \mathrm{C}\right.$ and $90-95 \% \mathrm{RH}$ ) for five months, even with 12 foliar calcium sprays per season (Ernani et al. 2008).

Thus, foliar calcium application may not be effective in increasing calcium content in apples and could therefore be replaced by soil application, in order to decrease production costs. However, soil application of calcium has to be tested in terms of efficiency to increase calcium content in the fruit. No literature reference was found regarding the efficiency of calcium sources applied to soil, when compared to foliar application in apple trees.

This study aimed to investigate the efficiency of different calcium sources applied to the soil, when compared to foliar calcium application, in terms of calcium content in the soil, leaves and fruit, as well as yield and fruit quality of 'Fuji' apple trees.

\section{MATERIAL AND METHODS}

The experiment was conducted in a commercial 'Fuji' apple orchard, grafted onto Marubakaido rootstock, in two crop seasons (2008/2009 and
2009/2010). Plants were 10 years old, spaced $5.5 \mathrm{~m} \times 3.7 \mathrm{~m}$ apart, and planted in aluminum-enriched Cambisolic Melanic Gleysol (Embrapa 2013), in Palmas (26 $34^{\circ} \mathrm{S}, 5^{\circ} 36^{\prime} \mathrm{W}$ and altitude of $1,280 \mathrm{~m}$ ), Paraná State, Brazil. The climate is classified as $\mathrm{Cfb}$, with mild summers, frequent winter frost, no established dry season and average temperatures in the coldest and hottest months of $18{ }^{\circ} \mathrm{C}$ and $22{ }^{\circ} \mathrm{C}$, respectively. Rainfall is well distributed throughout the year, with annual average precipitation ranging from 1,600 $\mathrm{mm}$ to $1,800 \mathrm{~mm}$ (Caviglione et al. 2000).

The chemical composition of the orchard soil was evaluated in September 2008 (before the application of calcium sources) (Tedesco et al. 1995). Four samples (corresponding to the experiment blocks) were collected. The average composition of the soil at depths of $0-20 \mathrm{~cm}$ and $20-40 \mathrm{~cm}$ were respectively: organic matter $=$ $107.9 \mathrm{~g} \mathrm{dm}^{-3}$ and $78.1 \mathrm{~g} \mathrm{dm}^{-3} ; \mathrm{P}=23.9 \mathrm{mg} \mathrm{dm}^{-3}$ and $11.5 \mathrm{mg} \mathrm{dm}^{-3} ; \mathrm{K}=0.38 \mathrm{cmol}_{\mathrm{c}} \mathrm{dm}^{-3}$ and $0.18 \mathrm{cmol}_{\mathrm{c}} \mathrm{dm}^{-3}$; $\mathrm{Ca}=12.7 \mathrm{cmol}_{\mathrm{c}} \mathrm{dm}^{-3}$ and $8.6 \mathrm{cmol}_{\mathrm{c}} \mathrm{dm}^{-3} ; \mathrm{Mg}=$ $5.1 \mathrm{cmol}_{\mathrm{c}} \mathrm{dm}^{-3}$ and $2.9 \mathrm{cmol}_{\mathrm{c}} \mathrm{dm}^{-3} ; \mathrm{Al}=0 \mathrm{cmol}_{\mathrm{c}} \mathrm{dm}^{-3}$ and $1.0 \mathrm{cmol}_{\mathrm{c}} \mathrm{dm}^{-3}$; SMP Buffer Index $=5.7$ and 4.9; $\mathrm{pH}\left(\mathrm{CaCl}_{2}\right)=5.4$ and 4.6; $\mathrm{V}(\%)=75.9$ and 47.3; $\mathrm{CTC}=28 \mathrm{cmol}_{\mathrm{c}} \mathrm{dm}^{-3}$ and $24.8 \mathrm{cmol}_{\mathrm{c}} \mathrm{dm}^{-3} ; \mathrm{Ca}: \mathrm{Mg}$ ratio $=2.5$ and $3 ; \mathrm{Ca}: \mathrm{K}$ ratio $=31.8$ and 43 .

A complete randomized blocks design was used with four replications and plots consisting of two 'Fuji' apple trees. At least one plant in the plot of each block and one row of plants among the plots were used as boundary lines. Treatments consisted of seven calcium sources: T1 - control (no calcium application); $\mathrm{T} 2$ - calcium chloride, $\mathrm{CaCl}_{2}\left(24 \% \mathrm{Ca}^{2+}\right)$; T3 - gypsum $\left(16 \% \mathrm{Ca}^{2+}\right.$ and $\left.13 \% \mathrm{~S}\right)$; T4 - Nitrabor ${ }^{\circledR}$ $\left(19 \% \mathrm{Ca}^{2+}, 15.5 \% \mathrm{~N}\right.$ and $\left.0.3 \% \mathrm{~B}\right)$; T5 - hydrated lime $\left(46 \% \mathrm{Ca}^{2+}\right)$; $\mathrm{T} 6$ - pulp sludge $\left(29 \% \mathrm{Ca}^{2+}\right)$; $\mathrm{T} 7$ foliar spraying with calcium chloride.

Soil application consisted of $80 \mathrm{~kg} \mathrm{ha}^{-1}$ of calcium distributed in three applications 60 days apart: 1) at full bloom; 2) when fruits were approximately $2 \mathrm{~cm}$ in diameter; 3) when fruits were about $5 \mathrm{~cm}$ in diameter. For application, a linear furrow $(10 \mathrm{~cm}$ wide, $5 \mathrm{~cm}$ deep) was opened on either side of the two plants in the plot, where calcium source was distributed and then covered with soil. These applications were preceded by mowing and repeated in two crop seasons (2008/2009 and 2009/2010). For the foliar application (treatment 7), a total of 10 calcium chloride sprays were performed onto each crop 14 days apart, from 90 days after full bloom up 
to 7 days before the apples were harvested. A tractormounted turbine sprayer was used, with a flow rate of $1,000 \mathrm{~L} \mathrm{ha}^{-1}$ and concentration of $400 \mathrm{~g} 100 \mathrm{~L}^{-1}$ of the mixture.

Phytosanitary treatments (fungicides and insecticides) followed recommendations normally used for apple trees, as well as decisions of the orchard owner. In the second crop season (2009/2010) fertilization was carried out in September 2009 (before flowering), with $250 \mathrm{~kg} \mathrm{ha}^{-1}$ of an NPK (04-08-16) fertilizer, and in December 2009, with $170 \mathrm{~kg} \mathrm{ha}^{-1}$ of a $02-08-16$ fertilizer.

In both crop seasons (2008/2009 and 2009/2010), 30 days before harvesting, 50 leaves were collected from the middle portion of each plant, in the central part of the new shoots, totaling 100 leaves per plot (Suzuki \& Basso 2006). Potassium, calcium and magnesium contents were analyzed based on leaf dry matter (Tedesco et al. 1995). In addition, soil samples were collected for chemical analyses from each plot, at harvesting of both crop seasons, at depths of $0-20 \mathrm{~cm}$ and $20-40 \mathrm{~cm}$.

The ripe apples were picked and weighed to establish the average fruit weight and yield, calculated by measuring the average area occupied by the treetops (in $\mathrm{kg} \mathrm{m}^{-2}$ ). Two samples of 30 fruits per plant were separated. One sample was used to analyze the potassium, calcium and magnesium levels in the flesh and the other to determine physical and chemical characteristics (total soluble solids, titratable acidity and firmness). In the 2008/2009 season, a sample of 70 fruits from each plot was cold stored $\left(1{ }^{\circ} \mathrm{C}\right.$ and $\left.90-95 \% \mathrm{RH}\right)$ and physical and chemical characteristics (total soluble solids, titratable acidity and firmness) were determined at 90 and 180 days of storage.

Data normality was analyzed using the Shapiro-Wilk test, applying data transformation when necessary, and data were submitted to analyses of variance and the Scott-Knott test $(p \leq 0.05)$ for treatment comparison.

\section{RESULTS AND DISCUSSION}

Calcium content in the soil increased significantly at the depth of $20-40 \mathrm{~cm}$, in the $2008 / 2009$ season, and at the depths of $0-20 \mathrm{~cm}$ and $20-40 \mathrm{~cm}$, in the 2009/2010 season, with all sources applied on the soil. At the depth of $0-20 \mathrm{~cm}$, calcium content only rose significantly in the 2008/2009 season, when calcium chloride, Nitrabor ${ }^{\circledR}$ and pulp sludge were used (Table 1). As such, an accumulated effect of the treatments was observed in the second season, since a total of $160 \mathrm{~kg} \mathrm{ha}^{-1}$ of calcium was applied over the two cycles. This indicates that the calcium applied percolated through the soil profile, given the significant increase in calcium content at the depth of $20-40 \mathrm{~cm}$. The higher calcium content in this soil layer makes the balance in cation exchange capacity (CEC) more favorable for calcium than aluminum. This may enhance root growth in apple trees, since other authors have found that raising calcium content up to a depth of $40 \mathrm{~cm}$ resulted in increased rooting in 'Paluma' guava (Prado \& Natale 2004) and 'Valência' orange trees (Auler et al. 2011).

For the other soil characteristics assessed, only the $\mathrm{Ca}: \mathrm{K}$ ratio was affected by the calcium sources applied to the soil, showing a significant increase for almost all the calcium sources used at both soil depths and in both crop seasons (Table 1). This is due to the rise in soil calcium content and could lead to potassium deficiency in apple trees, since calcium and potassium exhibit competitive inhibition. Calcium and potassium compete for absorption through the plant roots (Marschner 2012). In order to minimize this effect, $420 \mathrm{~kg} \mathrm{ha}^{-1}$ of NPK fertilizer containing $16 \%$ of $\mathrm{K}_{2} \mathrm{O}$ were applied twice in the 2009/2010 season.

The calcium sources significantly increased the calcium content in 'Fuji' apple tree leaves in both crop seasons (Table 2), except for the hydrated lime applied in the 2008/2009 season and hydrated lime, Nitrabor $^{\circledR}$ and foliar spray with calcium chloride in the 2009-2010 season, which did not differ significantly from the control.

The potassium content of leaves was significantly lower than the control with calcium chloride, Nitrabor ${ }^{\circledR}$ and foliar calcium chloride application in both seasons and with pulp sludge in the 2009/2010 season (Table 2).

In general, leaves with higher calcium content had lower potassium levels, and leaf magnesium content was not significantly altered by the application of calcium sources. This may be due to competitive inhibition between calcium and potassium in the soil, since high calcium content reduces potassium absorption by the roots. On the other hand, inhibition did not occur between magnesium and calcium, despite the fact that competition between $\mathrm{Mg}$ and $\mathrm{Ca}$ is typically stronger than between potassium and calcium (Marschner 2012). This may have occurred 
Table 1. Potassium, calcium and magnesium content $\left(\mathrm{cmol}_{\mathrm{c}} \mathrm{dm}^{-3}\right)$ in the $0-20 \mathrm{~cm}$ and $20-40 \mathrm{~cm}$ soil layers of a 'Fuji' apple orchard after calcium application in the 2008/2009 and 2009/2010 crop seasons (Palmas, Paraná State, Brazil).

\begin{tabular}{|c|c|c|c|c|c|c|c|c|c|c|}
\hline \multirow{3}{*}{ Treatment } & \multicolumn{10}{|c|}{$2008 / 2009$} \\
\hline & \multicolumn{2}{|c|}{$\mathrm{K}$} & \multicolumn{2}{|c|}{$\mathrm{Ca}$} & \multicolumn{2}{|c|}{$\mathrm{Mg}$} & \multicolumn{2}{|c|}{$\mathrm{Ca}: \mathrm{Mg}$} & \multicolumn{2}{|c|}{ Ca:K } \\
\hline & $0-20 \mathrm{~cm}$ & $20-40 \mathrm{~cm}$ & $0-20 \mathrm{~cm}$ & $20-40 \mathrm{~cm}$ & $0-20 \mathrm{~cm}$ & $20-40 \mathrm{~cm}$ & $0-20 \mathrm{~cm}$ & $20-40 \mathrm{~cm}$ & $0-20 \mathrm{~cm}$ & $20-40 \mathrm{~cm}$ \\
\hline Control & $0.33^{\mathrm{ns}}$ & $0.22^{\mathrm{ns}}$ & $11.72 b$ & $7.96 \mathrm{~b}$ & $5.00^{\mathrm{ns}}$ & $4.68^{\mathrm{ns}}$ & $2.34^{\mathrm{ns}}$ & $2.37^{\mathrm{ns}}$ & $35.50 \mathrm{~b}$ & $33.24 b$ \\
\hline $\mathrm{CaCl}_{2}$ & 0.29 & 0.21 & $13.25 \mathrm{a}$ & $10.57 \mathrm{a}$ & 5.18 & 3.95 & 2.56 & 2.98 & $45.69 \mathrm{a}$ & $47.62 \mathrm{a}$ \\
\hline Gypsum & 0.32 & 0.18 & $12.09 \mathrm{~b}$ & $11.87 \mathrm{a}$ & 4.87 & 4.19 & 2.48 & 3.05 & $38.37 \mathrm{~b}$ & $56.73 \mathrm{a}$ \\
\hline Nitrabor $^{\circledR}$ & 0.32 & 0.20 & $14.36 \mathrm{a}$ & $10.86 \mathrm{a}$ & 4.78 & 4.47 & 3.00 & 2.86 & $45.60 \mathrm{a}$ & $41.62 \mathrm{~b}$ \\
\hline Hydrated lime & 0.28 & 0.20 & $12.78 \mathrm{~b}$ & $11.01 \mathrm{a}$ & 5.06 & 4.50 & 2.52 & 2.68 & $45.64 \mathrm{a}$ & $67.02 \mathrm{a}$ \\
\hline Pulp sludge & 0.30 & 0.19 & $15.16 \mathrm{a}$ & $11.08 \mathrm{a}$ & 4.81 & 3.85 & 3.15 & 3.81 & $50.96 \mathrm{a}$ & $51.01 \mathrm{a}$ \\
\hline CV (\%) & 15.20 & 18.10 & 14.40 & 20.70 & 25.30 & 37.80 & 29.70 & 20.30 & 23.20 & 28.90 \\
\hline $\mathrm{F}$ & 1.71 & 1.21 & 3.25 & 4.42 & 1.38 & 1.39 & 2.22 & 1.90 & 3.58 & 2.92 \\
\hline Significance & 0.19 & 0.32 & 0.03 & 0.01 & 0.29 & 0.28 & 0.11 & 0.16 & 0.02 & 0.05 \\
\hline \multirow{2}{*}{ Treatment } & \multicolumn{10}{|c|}{$2009 / 2010$} \\
\hline & $0-20 \mathrm{~cm}$ & $20-40 \mathrm{~cm}$ & $0-20 \mathrm{~cm}$ & $20-40 \mathrm{~cm}$ & $0-20 \mathrm{~cm}$ & $20-40 \mathrm{~cm}$ & $0-20 \mathrm{~cm}$ & $20-40 \mathrm{~cm}$ & $0-20 \mathrm{~cm}$ & $20-40 \mathrm{~cm}$ \\
\hline Control & $0.29^{\mathrm{ns}}$ & $0.19^{\text {ns }}$ & $11.94 \mathrm{~b}$ & $7.22 \mathrm{~b}$ & $4.91^{\mathrm{ns}}$ & $2.92^{\mathrm{ns}}$ & $2.43^{\mathrm{ns}}$ & $2.48^{\mathrm{ns}}$ & $41.17 \mathrm{~b}$ & $38.02 \mathrm{c}$ \\
\hline $\mathrm{CaCl}_{2}$ & 0.29 & 0.22 & $15.86 \mathrm{a}$ & $10.50 \mathrm{a}$ & 5.02 & 3.41 & 3.16 & 3.08 & $54.69 \mathrm{a}$ & $48.84 \mathrm{~b}$ \\
\hline Gypsum & 0.33 & 0.18 & $16.28 \mathrm{a}$ & $12.27 \mathrm{a}$ & 4.86 & 2.92 & 3.35 & 4.20 & $49.32 \mathrm{a}$ & $68.17 \mathrm{a}$ \\
\hline Nitrabor $^{\circledR}$ & 0.27 & 0.21 & $15.80 \mathrm{a}$ & $10.94 \mathrm{a}$ & 5.04 & 3.61 & 3.13 & 3.03 & $57.98 \mathrm{a}$ & $51.48 \mathrm{~b}$ \\
\hline Hydrated lime & 0.28 & 0.17 & $16.85 \mathrm{a}$ & $10.77 \mathrm{a}$ & 4.87 & 4.02 & 3.46 & 2.68 & $60.18 \mathrm{a}$ & $63.37 \mathrm{a}$ \\
\hline Pulp sludge & 0.30 & 0.20 & $17.70 \mathrm{a}$ & $9.60 \mathrm{a}$ & 5.17 & 3.14 & 3.42 & 3.06 & $58.51 \mathrm{a}$ & $47.38 \mathrm{~b}$ \\
\hline CV (\%) & 22.00 & 25.40 & 15.90 & 21.50 & 23.60 & 26.70 & 34.60 & 30.30 & 20.50 & 28.80 \\
\hline $\mathrm{F}$ & 1.00 & 1.81 & 6.46 & 3.64 & 1.95 & 1.00 & 1.72 & 1.48 & 2.90 & 3.05 \\
\hline Significance & 0.45 & 0.17 & 0.00 & 0.02 & 0.14 & 0.48 & 0.19 & 0.25 & 0.05 & 0.04 \\
\hline
\end{tabular}

${ }^{n s}$ not significant, according to the F test $(\mathrm{p}>0.05)$. Means followed by different letters differ by the Scott-Knott test $(\mathrm{p} \leq 0.05)$. Data normality was confirmed for all variables by the Shapiro-Wilk test $(\mathrm{p} \leq 0.05)$, except for the calcium $(\mathrm{Ca})$ results, which required transformation (square root).

Table 2. Potassium, calcium and magnesium contents in the leaves ( $\mathrm{g} \mathrm{kg}^{-1}$ of dry matter) of 'Fuji' apple trees after application of calcium sources in two crops (2008/2009 and 2009/2010) (Palmas, Paraná State, Brazil).

\begin{tabular}{|c|c|c|c|c|c|c|}
\hline \multirow{2}{*}{ Treatment } & \multicolumn{2}{|c|}{$\mathrm{K}$} & \multicolumn{2}{|c|}{$\mathrm{Ca}$} & \multicolumn{2}{|c|}{$\mathrm{Mg}$} \\
\hline & Crop 1 & Crop 2 & Crop 1 & Crop 2 & Crop 1 & Crop 2 \\
\hline Control & $2.58 \mathrm{a}$ & $1.88 \mathrm{a}$ & $1.49 \mathrm{~b}$ & $1.30 \mathrm{~b}$ & $0.37^{\mathrm{ns}}$ & $0.28^{\mathrm{ns}}$ \\
\hline $\mathrm{CaCl}_{2}$ & $2.17 \mathrm{~b}$ & $1.46 \mathrm{~b}$ & $1.69 \mathrm{a}$ & $1.60 \mathrm{a}$ & 0.38 & 0.32 \\
\hline Gypsum & $2.50 \mathrm{a}$ & $2.10 \mathrm{a}$ & $1.68 \mathrm{a}$ & $1.78 \mathrm{a}$ & 0.37 & 0.40 \\
\hline Nitrabor $^{\circledR}$ & $2.10 \mathrm{~b}$ & $1.53 \mathrm{~b}$ & $1.73 \mathrm{a}$ & $1.34 \mathrm{~b}$ & 0.41 & 0.40 \\
\hline Hydrated lime & $2.33 \mathrm{a}$ & $1.81 \mathrm{a}$ & $1.36 \mathrm{~b}$ & $1.33 \mathrm{~b}$ & 0.37 & 0.38 \\
\hline Pulp sludge & $2.50 \mathrm{a}$ & $1.60 \mathrm{~b}$ & $1.65 \mathrm{a}$ & $1.51 \mathrm{a}$ & 0.37 & 0.40 \\
\hline Foliar & $2.10 \mathrm{~b}$ & $1.60 \mathrm{~b}$ & $1.73 \mathrm{a}$ & $1.43 \mathrm{~b}$ & 0.36 & 0.32 \\
\hline CV (\%) & 11.60 & 14.50 & 15.10 & 17.80 & 11.30 & 11.20 \\
\hline $\mathrm{F}$ & 3.17 & 3.61 & 3.01 & 2.92 & 1.19 & 1.78 \\
\hline Significance & 0.03 & 0.02 & 0.03 & 0.04 & 0.35 & 0.28 \\
\hline
\end{tabular}

ns not significant according to the F test $(\mathrm{p}>0.05)$. Means followed by different letters in the columns differ by the Scott-Knott test $(\mathrm{p}=0.05)$. Data normality was confirmed for all variables by the Shapiro-Wilk test $(\mathrm{p}=0.05)$, except for potassium $(\mathrm{K})$ results, which required inverse transformation $(1 / \mathrm{x})$.

because the potassium content in the orchard's soil was initially at a medium level, whereas soil magnesium content was initially high. Since the magnesium level was high, there was no imbalance in the content of these two ions to the point of causing inhibition.

Calcium content in fruits was higher when gypsum and pulp sludge were applied to the soil in the 2009/2010 crop season, differing significantly from the control and other calcium sources (Table 3). The calcium sources did not affect potassium or magnesium content in the fruits of either season and the calcium content in the first crop season. Although higher calcium content was recorded in the soil and leaves of 'Fuji' apple trees in both crops, this effect was only observed in fruits 
Table 3. Fruit potassium, calcium and magnesium contents ( $\mathrm{mg} \mathrm{kg}^{-1}$ of flesh), average fruit weight ( $\mathrm{g}$ ) and fruit yield ( $\left.\mathrm{kg} \mathrm{m}^{-2}\right)$ in 'Fuji' apple trees after application of calcium sources in the 2008/2009 and 2009/2010 crop seasons (Palmas, Paraná State, Brazil).

\begin{tabular}{|c|c|c|c|c|c|c|c|c|c|c|}
\hline \multirow{2}{*}{ Treatment } & \multicolumn{2}{|c|}{$\mathrm{K}$} & \multicolumn{2}{|c|}{$\mathrm{Ca}$} & \multicolumn{2}{|c|}{$\mathrm{Mg}$} & \multicolumn{2}{|c|}{ Fruit weight } & \multicolumn{2}{|c|}{ Fruit yield } \\
\hline & Crop 1 & Crop 2 & Crop 1 & Crop 2 & Crop 1 & Crop 2 & Crop 1 & Crop 2 & Crop 1 & Crop 2 \\
\hline Control & $973.30^{\text {ns }}$ & $744.70^{\mathrm{ns}}$ & $44.80^{\text {ns }}$ & $70.70 \mathrm{~b}$ & $44.50^{\text {ns }}$ & $21.10^{\mathrm{ns}}$ & $166.70^{\mathrm{ns}}$ & $183.10^{\mathrm{ns}}$ & $16.10^{\mathrm{ns}}$ & $7.50^{\mathrm{ns}}$ \\
\hline $\mathrm{CaCl}_{2}$ & $1,032.80$ & 647.80 & 50.50 & $74.50 \mathrm{~b}$ & 49.30 & 19.90 & 173.70 & 181.00 & 19.10 & 9.30 \\
\hline Gypsum & $1,104.50$ & 703.70 & 45.00 & $86.50 \mathrm{a}$ & 51.80 & 20.70 & 161.20 & 180.00 & 16.20 & 7.80 \\
\hline Nitrabor $^{\circledR}$ & $1,124.80$ & 657.60 & 51.80 & $70.70 \mathrm{~b}$ & 53.50 & 22.90 & 172.40 & 184.40 & 18.20 & 10.30 \\
\hline Hydrated lime & $1,104.80$ & 762.40 & 50.00 & $71.00 \mathrm{~b}$ & 51.80 & 22.40 & 162.70 & 191.90 & 18.00 & 9.80 \\
\hline Pulp sludge & $1,317.30$ & 678.80 & 46.00 & $86.30 \mathrm{a}$ & 56.80 & 22.10 & 165.10 & 182.70 & 17.50 & 9.80 \\
\hline Foliar & $1,138.50$ & 707.50 & 41.00 & $67.40 \mathrm{~b}$ & 52.50 & 26.50 & 172.10 & 190.10 & 18.60 & 9.80 \\
\hline CV (\%) & 18.00 & 14.60 & 31.10 & 18.40 & 16.70 & 17.80 & 7.90 & 5.30 & 16.20 & 24.40 \\
\hline $\mathrm{F}$ & 1.87 & 2.37 & 1.17 & 3.27 & 2.00 & 1.86 & 1.54 & 1.76 & 1.33 & 1.15 \\
\hline Significance & 0.14 & 0.07 & 0.36 & 0.04 & 0.11 & 0.37 & 0.30 & 0.45 & 0.18 & 0.26 \\
\hline
\end{tabular}

${ }^{\mathrm{ns}}$ not significant by the F test $(\mathrm{p}>0.05)$. Means followed by different letters in the columns differ according to the Scott-Knott test $(\mathrm{p}=0.05)$. Data normality was confirmed in all variables by the Shapiro-Wilk test $(\mathrm{p}=0.05)$.

from the second season, with gypsum and pulp sludge application. This reinforces the difficulty of calcium to reach the fruits and the need for high calcium levels in the soil to increase its content in the fruit, since the calcium flow in the plant occurs exclusively via xylem (Ho et al. 1987, Chamel 1989).

The application of calcium sources during fruit growth and fractionation of the dose into three applications after full bloom is justified because the roots are most active during this period and therefore fruits can absorb the highest amount of calcium (Cheng \& Raba 2009). Moreover, it is important to underscore that there was no water shortage during the experiments, since drought can adversely affect calcium supply from the soil to fruit via xylem.

From May 2008 to April 2009, the total accumulated rainfall was $1,851 \mathrm{~mm}$ and the lowest accumulated precipitation occurred in July 2008 (46 mm). In the 2009/2010 season, the accumulated precipitation was $2,595 \mathrm{~mm}$, higher than in the previous cycle, with August 2009 registering the lowest accumulated rainfall index $(117 \mathrm{~mm})$, though still considered very high. Thus, it is clear that the months in which the highest rainfall rate was recorded in both crop seasons were those in which fruit and plant growth occurred, mainly from September to February. Therefore, no water shortage was observed.

The foliar application of calcium chloride did not increase calcium levels in 'Fuji' apples, indicating low uptake into the fruit and low redistribution efficiency from the leaves to the fruit. Corroborating this result, Ernani et al. (2008) also found that foliar calcium chloride application did not affect calcium concentration in the flesh of 'Gala' apples, in 5 of the 6 crop seasons assessed, despite spraying each crop 12 times. Neilsen \& Neilsen (2002) evaluated the effect of preharvest foliar calcium chloride application of three apple cultivars ('Gala', 'Fuji' and 'Jonagold') grown in Canada and found a small increase in fruit calcium content, depending on the year, cultivar and number of applications.

In the present study, in the second crop season, after two years of soil application of calcium, gypsum and pulp sludge, there was effective increase in the calcium content of fruits, when compared to all other sources, including foliar application, which showed no differences from the control.

Since the cost of foliar calcium application in apple orchards is high, soil-based sources can be used (particularly gypsum and pulp sludge). However, it is important to note that calcium uptake from the soil can only occur if there is no water restriction in the orchard.

Fruit yield ( $\mathrm{kg} \mathrm{m}^{-2}$ of treetop) and average weight were not significantly influenced by the calcium sources applied (Table 3). However, the fruit yield for the 2008/2009 harvest was almost doubled, when compared to the 2009/2010 season. The lower yield in the second harvest was observed in the entire apple-producing region of Palmas and can be explained by the high rainfall rate during flowering. A total of $306 \mathrm{~mm}$ was recorded in September 2009 and $196 \mathrm{~mm}$ in September 2008. The high rainfall rate may have compromised bee pollination and led to fewer apples in the second season.

The 'Fuji' apples analyzed at harvest exhibited lower titratable acidity with calcium application, 
in relation to the control, in the 2009/2010 season. Total soluble solids and firmness at harvest were not significantly influenced by the application of calcium sources (Table 4).

In the postharvest conservation test conducted on apples from the 2008/2009 season, the use of calcium sources resulted in firmer fruits, with lower titratable acidity, after 90 days of cold storage $\left(1{ }^{\circ} \mathrm{C}\right.$ and $90-95 \% \mathrm{RH}$ ), differing significantly from the control. This indicates the greatest potential for conservation up to 90 days of storage, since this effect was not observed in apples stored for 180 days. In 'Golden Delicious' apples, Siddiqui \& Bangerth (1995) also observed that preharvest calcium chloride spraying did not affect fruit firmness at harvest, but did improve firmness retention during storage.

Higher firmness may be explained by the fact that calcium provides greater rigidity to cell walls, thus promoting better postharvest conservation potential, as reported by Natale et al. (2005), in 'Paluma' guava trees. These authors concluded that guava trees grown in areas where lime was applied to soil before planting showed higher fruit calcium content three years after planting. Consequently, the cell walls and middle lamellae of these fruits were well-structured, when compared to guavas grown without lime application.

Amarante et al. (2009) point out that calcium contents in the flesh and peel of 'Gala' apples were above $55 \mathrm{mg} \mathrm{kg}^{-1}$ and $192 \mathrm{mg} \mathrm{kg}^{-1}$, respectively, with a low incidence of bitter pit. This physiological disorder did not occur in the apples of the present study. However, calcium content in the flesh was slightly below $55 \mathrm{mg} \mathrm{kg}^{-1}$, in the 2008/2009 harvest, and far higher than this in the second crop season (2009/2010), regardless of the treatment used, indicating low risk of bitter pit occurrence in the 'Fuji' apples under storage.

Danner et al. (2009) tested the same calcium sources applied to the soil in the present study in a 'Venus' grape vineyard and concluded that they resulted in higher calcium content in the soil, leaves

Table 4. Total soluble solids (TSS), titratable acidity (TA) and firmness of 'Fuji' apples after application of calcium sources at harvest, in the 2008/2009 and 2009/2010 crop seasons, and following 90 and 180 days of cold storage $\left(1{ }^{\circ} \mathrm{C}, 90-95 \% \mathrm{RH}\right)$, in the 2008/2009 crop season (Palmas, Paraná State, Brazil).

\begin{tabular}{|c|c|c|c|c|c|c|}
\hline \multirow{3}{*}{ Treatment } & \multicolumn{6}{|c|}{ At harvest } \\
\hline & \multicolumn{2}{|c|}{ TSS ( ${ }^{\circ}$ Brix) } & \multicolumn{2}{|c|}{ TA (\% malic acid) } & \multicolumn{2}{|c|}{ Firmness $\left(\mathrm{kgf} \mathrm{cm}^{-2}\right)$} \\
\hline & Crop 1 & Crop 2 & Crop 1 & Crop 2 & Crop 1 & Crop 2 \\
\hline Control & $13.45^{\mathrm{ns}}$ & $14.75^{\mathrm{ns}}$ & $0.27^{\mathrm{ns}}$ & $0.33 \mathrm{a}$ & $5.75^{\mathrm{ns}}$ & $7.64^{\mathrm{ns}}$ \\
\hline $\mathrm{CaCl} 2$ & 12.85 & 14.63 & 0.24 & $0.30 \mathrm{~b}$ & 5.36 & 7.85 \\
\hline Gypsum & 13.05 & 14.00 & 0.28 & $0.31 \mathrm{~b}$ & 5.44 & 7.76 \\
\hline Nitrabor $^{\circledR}$ & 12.97 & 13.78 & 0.27 & $0.26 \mathrm{c}$ & 5.70 & 7.60 \\
\hline Hydrated lime & 12.85 & 14.03 & 0.26 & $0.30 \mathrm{~b}$ & 5.49 & 7.18 \\
\hline Pulp sludge & 13.53 & 14.13 & 0.27 & $0.30 \mathrm{~b}$ & 5.32 & 7.26 \\
\hline Foliar & 12.15 & 14.15 & 0.26 & $0.29 \mathrm{~b}$ & 5.39 & 7.47 \\
\hline CV (\%) & 5.10 & 4.90 & 10.90 & 7.70 & 13.70 & 5.50 \\
\hline $\mathrm{F}$ & 1.01 & 1.42 & 1.29 & 3.35 & 1.89 & 1.17 \\
\hline \multirow[t]{2}{*}{ Significance } & 0.45 & 0.26 & 0.16 & 0.02 & 0.31 & 0.15 \\
\hline & \multicolumn{6}{|c|}{ After storage } \\
\hline \multirow{2}{*}{ Treatment } & \multicolumn{2}{|c|}{ TSS ( ${ }^{\circ}$ Brix) } & \multicolumn{2}{|c|}{ TA (\% malic acid) } & \multicolumn{2}{|c|}{ Firmness $\left(\mathrm{kgf} \mathrm{cm}{ }^{2}\right)$} \\
\hline & 90 days & 180 days & 90 days & 180 days & 90 days & 180 days \\
\hline Control & $13.20^{\mathrm{ns}}$ & $12.64^{\mathrm{ns}}$ & $0.23 \mathrm{a}$ & $0.11^{\mathrm{ns}}$ & $5.85 \mathrm{~b}$ & $6.61^{\mathrm{ns}}$ \\
\hline $\mathrm{CaCl} 2$ & 13.13 & 12.01 & $0.20 \mathrm{~b}$ & 0.12 & $6.80 \mathrm{a}$ & 6.45 \\
\hline Gypsum & 12.65 & 12.45 & $0.20 \mathrm{~b}$ & 0.11 & $6.76 \mathrm{a}$ & 6.47 \\
\hline Nitrabor $^{\circledR}$ & 13.10 & 11.13 & $0.20 \mathrm{~b}$ & 0.11 & $6.95 \mathrm{a}$ & 6.34 \\
\hline Hydrated lime & 12.58 & 12.55 & $0.20 \mathrm{~b}$ & 0.12 & $6.91 \mathrm{a}$ & 6.27 \\
\hline Pulp sludge & 12.65 & 12.58 & $0.21 \mathrm{~b}$ & 0.12 & $6.91 \mathrm{a}$ & 6.20 \\
\hline Foliar & 12.40 & 12.32 & $0.20 \mathrm{~b}$ & 0.11 & $6.74 \mathrm{a}$ & 6.25 \\
\hline CV (\%) & 6.50 & 11.10 & 6.90 & 10.60 & 4.40 & 5.10 \\
\hline $\mathrm{F}$ & 1.38 & 2.60 & 2.87 & 1.53 & 6.88 & 2.31 \\
\hline Significance & 0.27 & 0.06 & 0.04 & 0.23 & 0.00 & 0.09 \\
\hline
\end{tabular}

ns not significant by the F test $(\mathrm{p}>0.05)$. Means followed by different letters in the columns differ according to the Scott-Knott test $(\mathrm{p}=0.05)$. Data normality was confirmed in all variables by the Shapiro-Wilk test $(\mathrm{p} \leq 0.05)$. 
and fruits, and reduced postharvest weight loss, shatter and rottness in grapes. This pronounced effect may be due to the low calcium content $\left(6.5 \mathrm{cmol}_{\mathrm{c}} \mathrm{dm}^{-3}\right.$ at a depth of $0-15 \mathrm{~cm}$ ) in the vineyard soil before the treatment, when compared to the soil of the present study.

Calcium content in the soil, leaves and fruit of 'Fuji' apple trees increased with the application of gypsum and pulp sludge, even when the initial calcium content in the orchard soil was high. These two calcium sources are inexpensive, making them an attractive option to replace foliar calcium application (which is more expensive, given the need of several applications), provided there is no water shortage in 'Fuji' apple orchards.

\section{CONCLUSIONS}

1. The calcium sources applied to the soil increase the calcium content in the soil and leaves of apple trees, and also improve the firmness of 'Fuji' apples cold stored for 90 days.

2. The use of gypsum and pulp sludge rises calcium levels in the flesh of 'Fuji' apples after two soil applications in successive cycles.

3. Soil applied calcium sources can replace the foliar application traditionally used in apple orchards, in order to lower production costs, provided there is no water shortage.

\section{REFERENCES}

AMARANTE, C. V. T.; CHAVES, D. V.; ERNANI, P. R. Composição mineral e severidade de "bitter pit" em maçãs 'Catarina'. Revista Brasileira de Fruticultura, Jaboticabal, v. 28 , n. 1, p. 51-54, 2006.

AMARANTE, C. V. T.; ERNANI, P. R.; STEFFENS, C. A. Predição de "bitter pit" em maçãs 'Gala' por meio da infiltração dos frutos com magnésio. Revista Brasileira de Fruticultura, Jaboticabal, v. 31, n. 4, p. 962-968, 2009.

AMARANTE, C. V. T. et al. O teor de cálcio é indicativo da suscetibilidade de "bitter pit" em maçãs 'Fuji'. Revista Brasileira de Fruticultura, Jaboticabal, v. 33, n. 1, p. 180186, 2011.

AULER, P. A. M. et al. Calagem e desenvolvimento radicular, nutrição e produção de laranja 'Valência' sobre porta-enxertos e sistemas de preparo do solo. Pesquisa Agropecuária Brasileira, Brasília, DF, v. 46, n. 3, p. 254261, 2011.
BRACKMANN, A. et al. Aplicações pré-colheita de cálcio na qualidade pós-colheita de maçãs 'Fuji'. Ciência Rural, Santa Maria, v. 40, n. 6, p. 1435-1438, 2010.

CAViglione, J. H. et al. Cartas climáticas do Paraná. Londrina: Iapar, 2000. (CD ROM).

CHAMEL, A. R. Permeability characteristics of isolated Golden Delicious apple fruit cuticles with regard to calcium. Journal of the American Society for Horticultural Science, Mount-Vernon, n. 114, p. 804-809, 1989.

CHENG, L.; RABA, R. Accumulation of macro- and micronutrients and nitrogen demand-supply relationship of 'Gala'/'Malling 26' apple trees grown in sand culture. Journal of the American Society for Horticultural Science, Mount-Vernon, n. 134, p. 3-13, 2009.

DANNER, M. A. et al. Fontes de cálcio aplicadas no solo e sua relação com a qualidade da uva 'Vênus'. Revista Brasileira de Fruticultura, Jaboticabal, v. 31, n. 3, p. 881889, 2009.

EMPRESA BRASILEIRA DE PESQUISA AGROPECUÁRIA (Embrapa). Sistema brasileiro de classificação de solos. 3. ed. Brasília, DF: Embrapa Solos, 2013.

ERNANI, P. R. et al. Preharvest calcium sprays were not always needed to improve fruit quality of 'Gala' apples in Brazil. Revista Brasileira de Fruticultura, Jaboticabal, v. 30, n. 4, p. 892-896, 2008.

HO, L. C.; HAND, D. J.; FUSSELL, M. Improvement of tomato fruit quality by calcium nutrition. Acta Horticulturae, Wageningen, n. 481, p. 463-468, 1987.

LARA, I.; GARCÍA, P.; VENDRELL, M. Modifications in cell wall composition after cold storage of calciumtreated strawberry (Fragaria $\times$ ananassa Duch.) fruit. Postharvest Biology and Technology, Amsterdam, v. 34, n. 3, p. 331-339, 2004.

MARSCHNER, H. Mineral nutrition of higher plants. 3. ed. London: Elsevier, 2012.

MIQUELOTO, A. et al. Atributos fisiológicos, físicoquímicos e minerais associados à ocorrência de "bitter pit" em maçãs. Pesquisa Agropecuária Brasileira, Brasília, DF, v. 46, n. 7, p. 689-696, 2011.

NATALE, W.; PRADO, R. M.; MORO, F. V. Alterações anatômicas induzidas pelo cálcio na parede celular de frutos de goiabeira. Pesquisa Agropecuária Brasileira, Brasília, DF, v. 40, n. 12, p. 1239-1242, 2005.

NEILSEN, G. H.; NEILSEN, D. Effect of foliar zinc, form and timing of Ca sprays on fruit $\mathrm{Ca}$ concentration in new apple cultivars. Acta Horticulturae, Wageningen, n. 594, p. 435-443, 2002. 
PRADO, R. M.; NATALE, W. Calagem na nutrição de cálcio e no desenvolvimento do sistema radicular da goiabeira. Pesquisa Agropecuária Brasileira, Brasília, DF, v. 39, n. 10, p. 1007-1012, 2004.

SIDDIQUI, S.; BANGERTH, F. Effect of pre-harvest application of calcium on flesh firmness and cell-wall composition of apples: influence of fruit size. The Journal of Horticultural Science \& Biotechnology, Ashford, v. 70, n. 2, p. 263-270, 1995.

SUZUKI, A.; BASSO, C. Solos e nutrição da macieira. In: EMPRESA DE PESQUISA AGROPECUÁRIA E EXTENSÃO RURAL DE SANTA CATARINA(Epagri). A cultura da macieira. Florianópolis: Epagri, 2006. p. 341-380.
TEDESCO, M. J. et al. Análise de solo, plantas e outros materiais. 2. ed. Porto Alegre: UFRGS, 1995.

TELIAS, A. et al. The effect of calcium sprays and fruit thinning on bitter pit incidence and calcium content in 'Honeycrisp' apple. Journal of Plant Nutrition, New York, v. 29, n. 11, p. 1941-1957, 2006.

TOBIAS, R. B.; CONWAY, W. S.; SAMS, C. E. Cell wall composition of calcium-treated apples inoculated with Botrytis cinerea. Phytochemistry, London, v. 32, n. 1, p. 35-39, 1992.

WHITE, P. J.; BROADLEY, M. R. Calcium in plants. Annals of Botany, Oxford, v. 92, n. 4, p. 487-511, 2003. 